\title{
携帯電話に含有される微量有害物質のサブスタンス・ フロー分析
}

\author{
中野加都子 1,2 \\ 宮 部 修 -3,* \\ 尾 崎 平3 \\ 和田安彦 3 \\ 中島 謙 -4 \\ 長 坂 徹 也 ${ }^{4}$
}

\author{
1関西大学先端科学技術推進機構 \\ 2 神戸山手大学人文学部環境文化学科 \\ 3 関西大学大学院工学研究科 \\ ${ }^{4}$ 東北大学大学院環境科学研究科
}

J. Japan Inst. Metals, Vol. 71, No. 9 (2007), pp. 801-808 (C) 2007 The Japan Institute of Metals

\section{Substance Flow Analysis on Diffused Toxics Contained in End-of-Life Cellular Phone}

Kazuko Nakano ${ }^{1,2}$, Shuichi Miyabe ${ }^{3, *}$, Taira Ozaki³ Yasuhiko Wada ${ }^{3}$, Kenichi Nakajima ${ }^{4}$ and Tetsuya Nagasaka ${ }^{4}$

${ }^{1}$ Organization for Research and Development of Innovative Science and Technology (ORDIST), Kansai University, Suita 564-8680 ${ }^{2}$ Dept. for Environment and Culture, Faculty of Humanities, Kobe-Yamate University, Kobe 650-0004

${ }^{3}$ Graduate School of Engineering, Kansai University, Suita 564-8680

${ }^{4}$ Graduate School of Environmental Studies, Tohoku University, Sendai 980-8579

Various low-toxicity substances are contained in the high functional electronic products in recent years. Although there is a little quantity of low-toxicity substances in each electronic product, total amount of them has been increasing by the mass production of electronic products. This means they tends to diffuse into environment and it also results in the loss of valuable metals.

In this work, a substance flow analysis (SFA) on low-toxicity substances in used cellular phones as a typical example of high functional electronic commodity was carried out based on the actual condition of disposal which was acquired by the questionnaire applied to users and composition of cellular phone analyzed by ICP and EPMA. The amount of some scattered low-toxicity substances has been estimated. It was pointed out that establishment of the recycling system of cellular phones including used ones stored by users is very important in the view point of the avoidance of low-toxicity substance diffusion and recovery of valuable elements.

(Received February 9, 2007; Accepted June 27, 2007)

Keywords: cellular phone, toxics, substance flow analysis (SFA), diffused substances, storage of used cellular phone

\section{1. 緒言}

私たちの生活空間には様々な過程を経て環境中に排出され る有害な物質が存在し, 人の健康や生態系に悪影響を及ぼし ている. 日常的に使用する製品にも微量な有害物質が使われ ていることがあり, 使用済み後に適正に回収, 処理されない 場合にはそれらの拡散につながることがある.

特に, 近年の利便性の高い電気電子製品に含まれる微量有 害物質は, 個々の製品当たりの含有量は微量であっても生産 台数の急増により全体としての使用量は無視できないレベル であることが予想され，使用済み後にマテリアルフロー上で 不明確となる量が多い分だけ環境へ散逸拡散する恐れが払拭 できない.

急激に機能が向上しつつある電気電子製品の中でも, 家電

* 関西大学大学院生 (Graduate Student, Kansai University)
4 品目 (ブラウン管テレビ, 冷蔵庫, 洗濯機, エアコン) 扎よ びパソコンとディスプレイについては, 既に家電リサイクル 法，および資源有効利用促進法によって回収，リサイクルが 生産者に義務付けられている. 家電リサイクル法では今後, 液晶テレビ, 電子レンジ, 衣類乾懆機等にも対象範囲が拡大 されることが検討されている，しかし，普及が急激に拡大し ている携帯電話については, 通信事業各社, 業界が主体とな ったリサイクルシステムが構築されているものの, 法的な回 収は義務づけられていない。同時に, 使用済久携帯電話の回 收がユーザーの意思に任されていること, 保存されているア ドレス，メール，写真等のデータ利用や個人情報の流出防止 等のために使用済みとなった後でも退蔵されることが多いこ とから，使用済久携帯電話に含まれる物質フローを把握する ことは困難な状況にある. 物質フロー管理が不明確であるこ とは, 含有微量有害物質も使用済及後に行方不明となり, 拡 散につながる可能性が高く, 将来にわたって人の健康や生態 系に悪影響を及ぼすことにもなりかねない。 
本研究は, 近年普及が著しく, 法的な回収義務が課せられ ていない携帯電話を対象に，製品中に含まれる微量有害物質 の種類と量を独自に分析した，同時に，ユーザーの使用済み 携帯電話の処理実態を詳細に分析するためのアンケート調査 を実施した。それらによって携帯電話に含有される微量有害 物質のサブスタンス・フロー分析 (SFA: Substance Flow Analysis)を行い，使用済み後にマテリアルフロー上で行方 不明となり拡散につながる可能性が否定できない微量有害物 質の種類と量を推定した。また，回收体制が現状のままであ る場合，今後それらの物質の排出が時間的にどのような経過 をたどるかを，ひとつのケーススタディとして予測した。

\section{2. マテリアル・フロー分析とサブスタンス・フロー 分析}

資源制約型社会の到来が予想される中, 資源の消費と需要 の構造，および国際的な物質バランスを定量化するために， 物質フロー管理が必要不可欠な情報の一つとなっている．物 質フローの管理のために注目されているのがマテリアルフ ローアカウンティング (Material Flow Accounting)であり, その分析手法が MFA (Material Flow Analysis)である. マ テリアルフローアカウンティングとは，ある特定の対象範囲 （国，地域，産業など）の物質収支を定量化し，環境負荷や資 源消費を体系的に把握することで環境・資源効率を改善しよ うという調査であり，90 年代後半から欧州を中心に盛んに 行われるようになっているものである11.

サブスタンス・フロー分析 $(\mathrm{SFA})$ もこうした物質循環分 析手法の一つであるが，MFA ではマクロな資源や製品，お よび一般的な材料が対象とされるのに対し, SFA ではそれ らに含まれる化学物質や重金属など, 主として有害物質の管 理 ·適正処理の観点から重要となる物質を対象とするもので ある・

既に循環型社会構築に向けた各種法律が施行され，主要な 物質の回収が行われるようになっているものの, 微量物質に ついては経済的，技術的または回収システムが未整備なため に回収されていないことが多い。しかし，近年の高度な電気 電子製品には微量物質の中でも有害性のあるものが使われて いることがある．物質フロー管理を行っていく上で SFA が 重要なのは, 物質フロー全体としての適正な管理・処理に向 けた対策を促進するために，微量有害物質の収支を明らかに し，行き先を確認できるようにしておく必要があるからであ る.

有害物質のフローを生産段階で管理し得るシステムを構築 することの重要性については，日本でも 1999 年に，「特定 化学物質の環境への排出量の把握等および管理の改善の促進 に関する法律」2)により，PRTR(Pollutant Release and Transfer Register : 特定化学物質排出移動量届出制度)が制 度化されたことからもわかるように，社会的な取り組みが既 にはじめられている．有害物質のフローを管理し得るように するためには，製造時だけでなく，個々の製品の使用済み後 のフローを明らかにした SFA を行う必要がある。

\section{3. 使用済み携帯電話の現状}

\section{1 生産台数と使用済み製品の特徵}

情報通信ネットワーク産業協会のデータ3)によると, 2004 年度の携帯電話国内投入台数は約 4,477 万台 (国内生産台数 +輸入台数一輸出台数)である. また，同データを用いて筆 者らが携帯電話発売当初から 2004 年度末までに国内に投入 されたすべての台数を推定した結果は約 3 億 9,496 万台 (PHS を含む)である.

携帯電話の他の電気電子製品と異なる特徵は，一般的に 1 台当たりの使用期間が短いことである．2001 年までの平均 では，約 550 日でユーザーは端末を買い換えていると推定 されて抢り4)，買い換えのために不用となった携帯電話端末 は年間約 5,000 万台と推測されている5)。しかし，資源有効 利用促進法抢よび家電リサイクル法の指定製品々なっていな いため，現状では経済産業省の産業構造審議会による「廃棄 物処理・リサイクルガイドライン」を自主的に制定すること が求められているものの法的な回収義務はない.

また， 1 台当たり使用期間が短いことと並ぶ携帯電話の特 徵は，電話としての本来の通信機能だけでなく，(1)アドレス 帳，写真等のデータのバックアップ，(2)蓄積されている情報 の思い出として保存, (3)カメラ・ゲーム・目覚ましなど付帯 機能の利用，(4)個人情報の流出の防止，(5)愛着，およびス ペースをとらないために目的はないが何となく保管されやす い，等の理由により退蔵されやすいことである。なお，ここ で退蔵とは通信手段としての機能を使わず，使用済みとなっ た後もユーザー等の手元に保管されている状態を指す.

\section{2 物質フロー上の問題}

携帯電話の回収システムは, 既に通信事業者等の協力によ って構築されているが, 回収率 (回収台数/(各メーカーから の出荷台数 - 携帯電話. PHS 加入純増数)) は, 2003 年度で $24 \%, 2004$ 年度で $21 \%$ と低い状態である ${ }^{6)}$ 。 また，携帯電 話に金，銀，パラジウム等の微量貴金属が含まれていること は一般的に知られている，有価であるこれらの回収と元の物 質としての再資源化の必要性も既に認識され，技術的に高い 回収実績がある7,8).

一方，携帯電話本体に含まれる微量有害物質についてはそ の実態がほとんど把握されておらず，一般的には有害物質の 管理を目的とした回収の必要性も認識されていない。製品中 の微量有害物質の含有量は 1 台当たりでは微量であるた め，直ちに環境に悪影響を与えることはない。しかし，既に 述べた携帯電話の特徵により，使用済み製品の物質フロー 上，他の電気電子製品のリサイクル，処理処分とは異なる特 有の問題を引き起こす可能性がある。即ち，a.ユーザーの 意思により積極的に退蔵されているケースが多いことから, 使用済久携帯電話の排出時期，量，場所を予測しにくい，b. 機能向上のスピードアップ，多機能化の進展によって買い換 え頻度が増している，c. 小型であるために販売店等を通じ た回収以外の排出(自治体の可燃・不燃ごみ等への混入)が行 われやすい，等のことから長期間中に管理されずにマテリア ルフロー上で行方不明となる物質が増加し，拡散量の増加に 
つながることである。

\section{4. 本研究における調査・分析の実施内容}

\section{1 調査·分析目的}

携帯電話を対象に，含有微量有害物質に注目した SFA を 行い，微量有害物質の収支を予測し，使用済久後に行方不明 となり拡散につながる可能性が高い微量有害物質の種類と量 を推定する，また，回収体制が現状のままである場合，今後 それらの物質の排出が時間的にどのような経過をたどるかを 予測する。

\section{2 方 法}

\subsection{1 微量有害物質量の分析}

本研究では，携帯電話に含有される微量有害物質の対象々 して, PRTR の第 1 種指定物質に該当する $\mathrm{Ba}, \mathrm{Cr}, \mathrm{Pb}, \mathrm{Ni}$ の 4 種を取り上げ，これら各元素含有量の定量を本研究に扔い て独自に行った，第 1 種指定化学物質は，(1)人の健康を損 なう恐れ (吸入慢性毒性, 経口慢性毒性, 発ガン性, 変異原 性, 生殖/発生毒性, 感作性), または動植物の生息もしくは 生育の支障を及ぼす恐れがある，(2)自然作用による化学的変 化により容易に生成する化学物質が(1)に該当するもの，(3)才 ゾン層を破壊し, 太陽紫外線の地表に到達する量を増加させ ることにより人の健康を損なう恐れがあるもの，に該当し， かつその物理的化学性状，その製造，輸入，使用または生成 状況から見て，相当広範な地域の環境においてその化学物質 が継続して存すると認められる化学物質である. 各物質量 は，試料別に携帯電話部品の構成要素に分け，ステンレス製 リード線など，組成が明らかなものは部品を電子天秤で計量 することにより存在量を求めた. また, 微量有害物質は主と して基板に含まれていると考えられるため，ここでは基板中 に含まれる各対象物質量を王水による浸出液の ICP 分析お よび構成微小部品代表断面の EPMA 分析により定量した. 携帯電話を分解して取り出した基板をハンドミルで $2 \sim 3$ $\mathrm{mm}$ 角程度のチップに粉砕し，プラスチック類を選別，除外 した。引き続き，金属分に富んだ残分を秤量し，約 $60^{\circ} \mathrm{C} に$ 加熱された王水中にて 24 時間溶出処理を施した後，その濾 液を ICP 分析に供した．溶出試験後残渣には金属分は認め られなかったが，この処理は更にもう一度繰り返した．分析 は同一機種 2 台について行った。本研究の対象物質である $\mathrm{Ba}, \mathrm{Cr}, \mathrm{Pb}, \mathrm{Ni}$ は第 1 段目の処理でほぼ全量抽出できたとみ なせた ${ }^{8)}$ 。これらの分析結果を組み合わせると同時にクロス チェックを行うことにより, 携帯電話中の $\mathrm{Ba}, \mathrm{Cr}, \mathrm{Pb}, \mathrm{Ni}$ の 存在量を得た。

\subsection{2 ユーザーへのアンケート調査}

携帯電話・PHS におけるリサイクルの取り組み状況につ いては，電気通信事業者協会・情報通信ネットワーク産業協 会による調査結果6) が報告され，利用者を対象にしたアン ケート調查結果9) も公表されている。しかし，アンケート調 査結果 ${ }^{9)}$ が一部の人数を基本としたものになっていることも あり，それらから使用済みとなった携帯電話の台数を基本と した詳しい内訳は得られない。そこで, 筆者ら(関西大学,
東北大学，名古屋大学) は，独自に使用済久携帯電話に関す る台数ベースの処理実態を詳細に調べるためのアンケート調 查を実施した(実施期間：2005 年 8 月〜 10 月). 調査項目は, (1)携帯電話の所有の有無, (2)所有時期 - 機種 - 機種選択の理 由, (3)使用済久後の処理状況, (4)退蔵理由, (5)退蔵携帯電話 の処理機会 ·方法，(6)回収方法別の協力度，(7)買い取り制度 実施の場合の価格である．特に現在所有する携帯電話だけで なく，これまでに所有した携帯電話を過去最高 5 台前にさ かのぼって，それぞれすべてについて a. 機種分類，b. 契約 会社, c. 契約方法, d. 保管・処理方法まで詳しく回答を求 めた．本論文ではこのうち関連する項目のみを用いる.

なお，後述するように回答者の大部分が学生であることか ら，本アンケート結果が我が国全体の傾向を表すものである とは考えていない。しかしながら使用済久携帯電話に関する 統計データが極めて不足していることから，後に示す有害元 素の拡散ポテンシャルについて可能な限り代表例を示すケー ススタディを行うために，そのベースデータとするためのア ンケートを実施した、今後，業界等による大規模な年代層別 アンケート調査の実施を期待するものである.

\section{3 携帯電話の分類と対象とした微量有害物質および範囲}

携帯電話は，それらに含まれる物質は製品機能によって異 なるため，含有物質も機能別に推定する必要がある。一般的 に携帯電話は第 1 世代(アナログ方式)，第 2 世代 (デジタル 方式), 第 3 世代 (高速データ通信可能, モバイルマルチメ ディア）と分類されるため，世代別に検討することが妥当で ある。しかし，PHS は第 2 世代と位置づけられているが， 生産台数の統計資料等においては携帯電話の分類が「PHS」 と「PHS 以外」と扱われていることから，本研究に沶いて は携帯電話を, type 1:PHSのみ, type 3 : 第 3 世代の携 帯電話とし，それ以外の携帯電話を type 2 と分類した.

仕様が多種多様にわたり，個々の使用台数に大きな差があ ると思われる携帯電話において，全ての機種を分析すること は現実的ではない，そのため，本研究では各タイプにおいて Table 1 を具備すべき諸機能として掲げ，これらを満足し， かつ type I と type III では 2004 年度までの期間で最も出荷 台数シェアの多かったメーカーのものを試料とした. type II については出荷台数シェアにメーカーによる差は見られなか ったため，特にメーカーを特定しなかった．本研究では試料 として選択した機種を対象とした分析結果を基に $\mathrm{Pb} ， \mathrm{Ba}$,

Table 1 Content of each cellular phone.

\begin{tabular}{|c|c|c|c|}
\hline Sample & $\begin{array}{l}\text { Sales } \\
\text { time }\end{array}$ & Function & System \\
\hline $\begin{array}{c}\mathrm{I} \\
\text { (type } 1)\end{array}$ & 1994 & $\begin{array}{l}\text { Voice communication } \cdot E-\text { ma- } \\
\text { il } \cdot \text { Short mail }\end{array}$ & $\begin{array}{l}\text { Personal Handyphone } \\
\text { System (PHS) }\end{array}$ \\
\hline $\begin{array}{c}\text { II } \\
\text { (type 2) }\end{array}$ & 2001 & $\begin{array}{l}\text { Voice communication } \cdot \mathrm{E}-\mathrm{ma}- \\
\text { il } \cdot \text { Camera } \cdot \text { Internet } \cdot \text { Low }- \\
\text { speed data communications }\end{array}$ & Cellular phone \\
\hline $\begin{array}{c}\text { III } \\
\text { (type } 3)\end{array}$ & 2005 & $\begin{array}{l}\text { Voice communication } \cdot \text { E-ma- } \\
\text { il } \cdot \text { Camera } \cdot \text { Internet } \cdot \text { Low - } \\
\text { speed data communications. } \\
\text { High-speed data communica- } \\
\text { tions } \text { TV telephone } \cdot \text { Games } \\
\text { Cyber-money Music Repro- } \\
\text { duction }\end{array}$ & Cellular phone \\
\hline
\end{tabular}


$\mathrm{Cr}, \mathrm{Ni}$ の物質量を推定することにした。

また，本 SFAにおいては，発売当初から 2004 年度末ま でに生産されたすべての携帯電話の生産のために使われた対 象微量有害物質の投入に関する使用済久後の収支を分析す る.そのことによって使用済久後に行方不明となり，拡散に つながる可能性がある微量有害物質の種類と量の推定, およ び今後の排出の時間的推移の予測を行う.なお, 本研究では 携帯電話本体のみを対象とし, 電池は対象外とした.

\section{4 これまでの研究との関係}

著者らはこれまでの論文10)で, 製品の使用後プロセスで は有価または純度の高い資源の回収が優先され，製品に含ま れる微量な物質は有害性があっても管理者不明の状態で行方 不明となってきた問題を指摘した。その上で，微量有害物質 がリサイクル，処理処分プロセス中で拡散する量を推算し， それらがもたらす有害性のポテンシャルを潜在的有害性とし て指標化し，エネルギー消費関連の環境負荷と組み合わせて 評価する手法を提示した.

本研究に打いては, 有害性をテーマとしているが, 既論 文10)では LCA 手法を参考に, 複写機を事例としてエネル ギー消費関連の環境負荷と潜在的有害性強度を組み合わせて 製品中で回収する部品またはユニットの優先順位を評価する 手法を提示したのに対し, 本論文では物質フローに注目し, SFAの視点から使用済み後のフローが不明となっている微 量有害物質の種類と量, およびそれらの時間的経緯を予測す ることが目的である. また，携帯電話に含有される微量有害 物質を対象としたSFAはこれまでに行われた例がない.

\section{5. 結果}

\section{1 微量有害物質の分析}

4.2.1 に示した分析のために行った分解例を Fig. 1 に示し た. 分析により推定した各タイプ別の 1 台当たりの対象 4 物質量を Table 2 に示した.

携帯電話の製造会社が異なるため, 年次傾向の直接的な比 較は困難ではあるが, Type 3 の携帯電話への変化に伴い, (a) 含有鉛量の減少傾向, および (b)クロム含有量の増加傾 向が示された. 含有鉛量の減少は, 鉛フリーはんだの導入に よる効果であると考えられる.なお，化学分析の結果によ り, 微量の鉛含有が確認されたが, これは, ボタン電池など 他の鉛利用部品による鉛の混入であると考えられる. 一方, クロム含有量の増加は, ステンレス鋼利用量の増加がその原 因であると考えられる。

\section{2 ユーザーへのアンケート調査}

\subsection{1 回答者の属性}

設問が複雑であり，回答に手間と時間がかかることから， 回答者は著者らの所属する大学, および関係する大学の工学 部の学生を中心とし, 講義終了後等の時間を利用して調査票 を配布・回収した．若年層の男性が多くなるのを補完するた め, 大学事務職員, 卒業生, 婦人大学の主婦層にも調査への 回答を依頼した。回答者数は計 782 名であり, 有効回答率

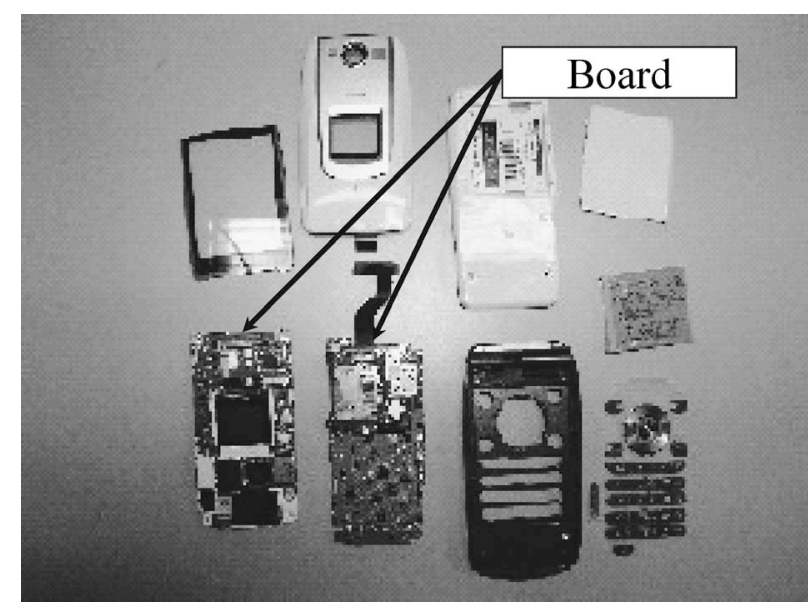

Fig. 1 Cellular phone after dismantlement (type 3).

Table 2 Amount of 4 substances in each cellular phone. unit : $\mathrm{g} /$ cellular phone

\begin{tabular}{|c|c|c|c|c|}
\hline \multirow{2}{*}{ Element } & \multirow{2}{*}{ Contained parts } & type 1 & type 2 & type 3 \\
\hline & & Sample I & Sample II & Sample II \\
\hline $\mathrm{Pb}$ & $\begin{array}{l}\text { Board, Stainless parts, } \\
\text { Button battery }\end{array}$ & 0.35 & 0.26 & 0.01 \\
\hline $\mathrm{Ba}$ & $\begin{array}{l}\text { Board, Stainless parts, } \\
\text { Button battery }\end{array}$ & 0.50 & 0.55 & 0.39 \\
\hline $\mathrm{Cr}$ & $\begin{array}{l}\text { Board, Stainless parts, } \\
\text { Button battery }\end{array}$ & 0.06 & 0.05 & 0.62 \\
\hline $\mathrm{Ni}$ & $\begin{array}{l}\text { Board, Stainless parts, } \\
\text { Button battery }\end{array}$ & 0.68 & 0.51 & 0.74 \\
\hline
\end{tabular}

は 83.6\%であった. 回答者の属性は, 学生 : $63 \%$, 一般 人：37\%，性別では男性： $72 \%$, 女性 : $25 \%$ (無回答 : $3 \%$ ) である。

\section{2 .2 ユーザーにおける携帯電話の処理方法}

使用済久携帯電話のユーザーにおける処理方法については この設問への有効回答数 654 の中から, 今まで携帯電話を 1 台しか持ったことのない人，および携帯電話を持っていない 人を除いた $(n=514)$. 対象者に抢ける総使用済久携帯台数 は 1,181 台であり, 処理方法は台数ベースで販売店返却 : 31\%, 退蔵： $47 \%$, 不然物等として処理 : 4\%であった。 た，回答の選択肢として「自宅にはあるがどこにあるかわか らない」,「紛失」,「所有者変更」は，管理する主体が不明確 となるため, 対象物質のフロー上で行方不明となる可能性の 高い状態であると考え，その割合は $18 \%$ となった(Fig. 2). ここでは, この割合を「使用済久後に行方不明となり, 拡散 につながる可能性が高い」割合に該当すると考えた．また， 有害物質を管理する主体が不明確な状態で物質フロー上にお いて行方不明になることは, 結果的に環境中にばらまかれる ことになる意味でこの割合を拡散 (diffused) と呼ぶことにし た.

また，上記に示した販売店返却割合である $31 \%$ は式 ( 1 ) によって求めた割合であり, 電気通信事業者協会・情報通信 ネットワーク産業協会によって公表されている回収率6)であ る式 ( 2 )によって計算される回収率とは区別する必要があ る。 


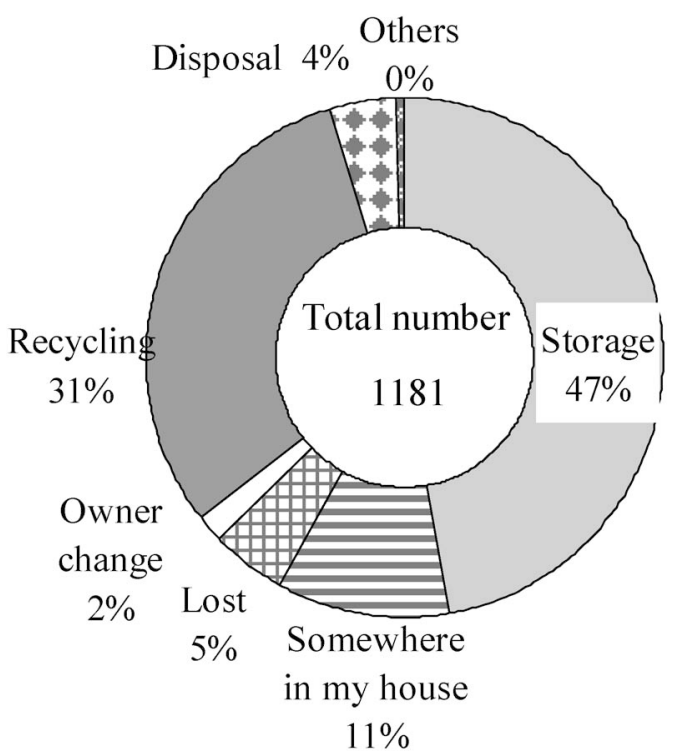

Fig. 2 Disposal method for used cellular phones by users.

\section{使用済及携帯電話の販売店返却率}

$=$ 販売店等に返却された総台数 $/$ 使用済みとなった携帯 電話総台数 $\times 100$

回收率

$=$ 回収台数 $/($ 各メーカーからの出荷台数 - 携帯電話. PHS 加入純増数 $) \times 100$

\subsubsection{1 台当たり平均使用期間}

\section{（1）アンケート調査結果による 1 台当たり平均使用期間}

本研究に打ける携帯電話 1 台当たりの平均使用期間は, 携帯電話が通信媒体として機能していた期間とし, 初めて携 帯電話を所有した年度から 2004 年度末までの使用期間を過 去に所有した携帯電話台数(現在所有しているものも含む)で 除したものとする. 1 台当たりの平均使用期間は以下の式に 示す.

$$
Y_{-} A_{(j)}=\left[2005 \text { 年 }-\left(Y_{-} S_{(j)}\right)\right] /\left(\sum_{i=1}^{3} N_{-} M_{(i, j)}\right)
$$

ここで, $Y_{-} S_{(j)}$ : 初期購入年度, $N_{-} M_{(i, j)}$ : 現在も含む過 去に所持した type $\mathrm{i}$ の携帯電話台数, $Y_{-} A_{(j)}$ : 携帯電話 1 台当たりの平均使用期間, $i:$ 各 $\operatorname{type}(i=1 \sim 3), j:$ 人数 $(j$ $=1 \sim 606$ 人)

各タイプ別平均使用期間は, 過去に携帯電話を所有したこ とのある人全員の各タイプ別合計使用期間を，次式のとお り，タイプ別合計台数で除することによって求めた.

$$
Y_{-} A_{(i)}=\left[\sum_{j=1}^{606}\left(N_{-} M_{(i, j)} \times Y_{-} A_{(j)}\right)\right] / \sum_{j=1}^{606} N_{-} M_{(i, j)}
$$

ここで, $N_{-} M_{(i, j)}$ : 携帯電話台数, $Y_{-} A_{(j)}$ : 携帯電話 1 台当たりの平均使用期間, $Y_{-} A_{(i)}$ : 各 type 別平均使用期間, $i$ : 各 type $(i=1 \sim 3), j:$ 人数 $(j=1 \sim 606$ 人)

この結果, 1 台当たり平均使用期間は, type 1:22 ケ月, type $2: 20$ ケ月, type 3:18 ケ月となった。なお, 式 (3) から各個人の携帯電話 1 台当たり平均使用期間を算出し, その結果を用いて式 (4)により全体としての各タイプ別平 均使用期間を算出したため，2001 年に type 3 のサービス開

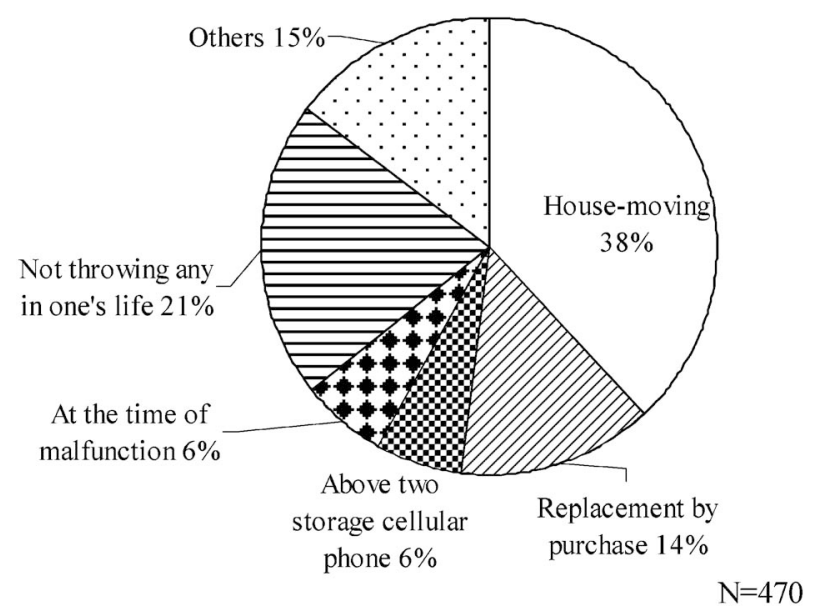

Fig. 3 Chance of disposal for storaged cellular phones.

始時期以来，経過年数の短い携帯電話の契約者数が急増した ことは平均使用期間に影響を与えない。

\section{（2）平均使用期間の補正}

アンケート調査では回答者の $63 \%$ が学生であるという偏 りが見られため, 年齢層別 (10 代〜 40 代の各年齢層と「50 代以上」の 5 区分の年齢層)の加重平均による補正を行っ た．ここでは総務省統計局により公開されている日本人人 口11) と，情報通信統計データベースにより公開されている 年齢層別の携帯電話利用率12) から各年齢層別の利用者数を 求め, それぞれの年齢層の利用者数の全利用者数に対する割 合を求めた. それによって求められた值 $\left(r_{i}\right)$ を用いて次式に より年齢を考慮した各タイプ別の平均使用期間を求めた.

$$
t_{i}=\sum_{k=1}^{5}\left(t_{i, k} \times r_{i}\right)
$$

ここで, $i:$ 各 type $(i=1 \sim 3), \quad k$ : 各年齢層 $(k=1 \sim 5)$, $t_{i, k}$ : アンケート調查で得られた各 type 年齢層による平均使 用期間, $t_{i}$ : 各 type 別平均使用期間 (補正有り), $r_{i}$ : 全利用 者数に対する各年齢層別利用者数の割合

以上の結果, type 1 の平均使用期間は 25 ケ月, type 2 は 23 ケ月, type 3 は 20 ケ月となった. なお, アンケート回答 者属性では, 男女の割合にも偏りがみられたが, 平均使用期 間の差について $\mathrm{T}$ 検定を行った結果, 各タイプ, 全タイプ に颃いて平均使用期間に打ける差は見られなかった（5\%有 意).そのため, 男女差による補正は行わなかった。

以降の各タイプの携帯電話平均使用期間は, この年齢層に よる加重平均を行った数值を用いる.

\subsection{4 退蔵携帯電話を返却または処理する機会}

アンケート調査結果では, 退蔵している使用済み携帯電話 を返却または処理する機会については,「引っ越し時」が 38\% で最も多い，その次に「生きている間は捨てるつもりはない」 の $21 \%$ であり，「買い換え時」の $14 \%$ より多くなっている (Fig. 3).「引っ越し時」が最も多いという結果からは, 退 蔵している携帯電話を積極的に返却または処理する意思は薄 く, どうしても所有物を整理する必要が生じた時には仕方な く手放すという傾向が見られる，むしろ，「生きている間は 捨てるつもりはない」が約 2 割を占めることから考えると, 
退蔵し続けることへの強い意思が伺える。しかし，長期間経 過後には保管場所を失念したり，小型であるだけに他の所有 物の中に紛れ込むことも多いことから，回収への何らかの積 極的な対策を講じない限り，使用済久携帯電話が管理者不明 の廃棄物となって，長期間経過後に排出される可能性が高い ことを示している.

な抢，退蔵携帯電話を返却または処理する機会について， アンケート調査結果から得られた回答者の年齢層による回答 への違いを比較したところ，年齢層による違いはほとんど見 られなかったため, 以降のケーススタディでは本調査結果で 求められた割合をそのまま用いることにした.

\section{6. 微量有害物質の SFA}

\section{1 使用済み携帯電話台数の推定}

本研究において分類した 3 つタイプすべてに関する生 産台数データが存在するのが 1997 年度以降であったため, 1997 年 4 月から 2004 年 3 月までの生産台数は統計データ3) を用い，それ以前の生産台数は 1997 年 3 月時点における加 入者数から推定し，1997 年度の生産台数に加えた. なお, 販売店へのヒヤリング調査, および統計データ3)において各 月の出荷台数が，各月の生産台数々前月末在庫台数の和とお およそ一致することから，生産された携帯電話はすべて市場 に投入されたと考えた.

使用済久携帯電話台数は, 各年度の月ごとの新規加入者数 が，その月からタイプ別の平均使用期間後に使用済みになる として推定した。その結果，2004 年度末までに生産された 携帯電話約 3 億 9,496 万台は 2007 年度末むでにすべて使用 済みとなる。

\section{2 使用済み携帯電話に含有される対象物質量と現状にお ける物質収支の推定}

\subsection{1 使用済み携帯電話に含有される対象物質量}

Table 2 で求めたタイプ別の 1 台当たりの対象 4 物質含有 量と，アンケート調査によるユーザーの処理方法割合を用い て，2004 年度末むでに国内市場に投入された総携帯電話に 含まれる各物質の使用済み後のフローを推定した.ここで, 輸入品も国内で使用済みとなること，および SFA を行う上 では輸出量も国内から海外への移動量として把握する必要が あることから，国内生産台数と輸入台数の合計に含まれる各 物質総量を純国内投入量とした(輸出台数分を差し引かない). 2004 年度末までの輸出を含む純国内投入台数は合計で 4 億 3,567 万台であり，タイプ別含有量をもとに算出した各物質 の純国内投入量は, $\mathrm{Pb}: 102$ t, Ba: 228 t, Cr: 53 t, Ni: 239 t と 推定される。

\subsection{2 物質収支の推定}

アンケート調査によって得られたユーザーの意思による処 理方法の比率 (Fig. 2)をタイプ別に分析し，タイプ別の各物 質の含有量，および補正後のタイプ別の 1 台当たり平均使 用期間を用いて，携帯電話に含まれる各物質の使用済み後の 状況を推定した結果を $\mathrm{Pb}$ を例として Fig. 4 に示した。 その 結果， 4 物質の純国内投入量に対する平均割合は，販売店返
却：約 23\%, 既に拡散 : 約 14\%, 退蔵：約 36\% となる。 $\mathrm{Ba}, \mathrm{Cr}, \mathrm{Ni}$ についてはその具体的な量を Table 3 に示した.

退蔵品の適切な回収対策が今後も確立されない場合は，退 蔵品に含まれる物質が拡散する可能性が高いこと，輸出され た製品が日本国内に回収される可能性は薄いことから，既拡 散に加えて退蔵, 輸出も拡散すると考えると, 使用済久携帯 電話生産のための純国内投入量に対する拡散する可能性があ る最大の割合は 4 物質の平均で $59 \%$ となる。

なお，本研究では 2004 年度末までの各物質投入量に対す る分析を行ったが，図中の「流通分」は，2004 年度に生産 された携帯電話として同年度末までの段階で流通段階にある 台数に該当し, メーカーや販売店等で管理されている状態で あるため, 拡散する可能性がある最大の割合から除外した.

\section{3 今後のサブスタンス・フローに関するケーススタディ}

退蔵品の今後の時間的排出状況を予測した。この予測を行 うために，Fig. 3 に示した退蔵携帯電話を返却または処理す る機会に関するアンケート調查の設問への回答結果を用い て，退蔵携帯電話が排出される時期を設定した．推定の前提 としては各回答項目の期間を以下のように考えた.

(1) 携帯電話買い換え時, 退蔵台数 2 台以上, 機能不全 時

この場合は，「次の携帯電話を購入する時期」とし， 1 台 当たり平均使用期間後とした. type 1 から type 3 の平均使 用期間が約 1.9 年であることから，2007 年度から 2 年後の 2009 年度末とした。

(2)引っ越し時

アンケート調査結果から, 平均 16.3 年に 1 回, 引っ越し

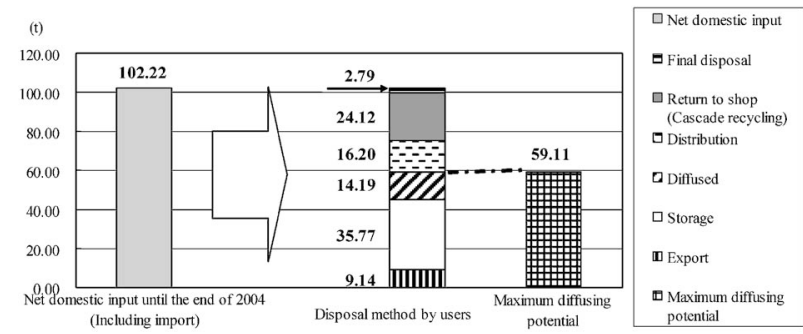

Fig. 4 Flow of substance in used cellular phones $(\mathrm{Pb})$.

Table 3 Flow of each substance in used cellular phones.

\begin{tabular}{crrrr}
\hline item & $\mathrm{Pb}$ & $\mathrm{Ba}$ & $\mathrm{Cr}$ & $\mathrm{Ni}$ \\
\hline $\begin{array}{c}\text { Net domestic input until the end of } \\
\text { 2004 (including import) }\end{array}$ & 102.22 & 228.29 & 53.32 & 239.15 \\
\hline Final disposal & 2.79 & 5.95 & 1.06 & 6.08 \\
\hline Return to shop (Cascade recycling) & 24.12 & 53.61 & 11.60 & 55.32 \\
\hline Distribution & 16.20 & 35.38 & 8.10 & 37.50 \\
\hline Diffused & 14.19 & 31.04 & 6.82 & 32.54 \\
\hline Storage & 35.77 & 80.89 & 20.52 & 85.81 \\
\hline Export & 9.14 & 21.42 & 5.21 & 21.90 \\
\hline Maximum diffusing potential & 59.11 & 133.35 & 32.55 & 140.25 \\
\hline
\end{tabular}


する結果が得られたため, 引っ越し時に排出される場合は 20 年後と考えた.

(3) 生きている間は捨てるつもりはない

平均寿命を 81.8 歳 ${ }^{13)}$ とし, 設問に対して「生きている間 は捨てるつもりはない」と回答した人の退蔵携帯電話は, 回 答者が平均寿命を迎えた時に排出されることと考えた。この 結果から 2004 年度末むでに生産された携帯電話の退蔵分 は, 回答者の年齢と平均寿命までの年数から, 2077 年度末 にすべて何らかの処理が行われることになる.

以上の結果を用いて， 2007 年度末 (タイプ別 1 台当たり平 均使用期間から，2004 年度末までに生産されたすべての携 帯電話が使用済久となる年), 2009 年度末 (携帯電話買い換 え時, 退蔵台数 2 台以上, 機能不全時), 2027 年度末 引っ 越し時)， 2077 年度末(ユーザーが寿命をむかえた時)の 4 段 階に分けて各物質のフローの推定を行った。 ここで, 退蔵品 の処理方法(販売店返却, 埋立, 拡散)についは, 「退蔵品を 捨てるとするとどう処理するか」というアンケート調査の設 問に対する回答割合を用いた，また，ここでの拡散とは，販 売店返却, 自治体のごみとして捨てる以外の方法で「どこか に捨てる」と回答した割合に該当する.

これらによって各物質の純国内投入量についてサブスタン

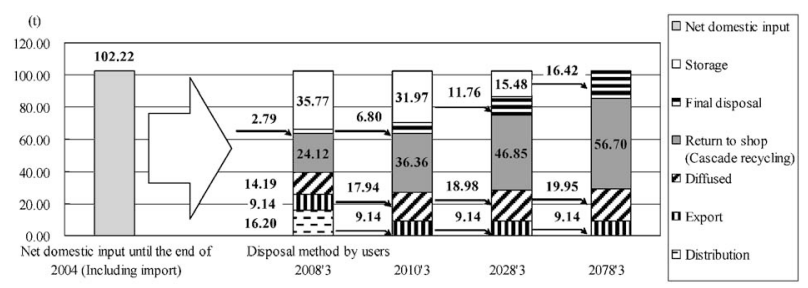

Fig. 5 Estimation of substance-flow at each time $(\mathrm{Pb})$.
ス・フローを予測した結果を $\mathrm{Pb}$ を例として Fig. 5 に示し た.なお，図中の「流通分」とはFig. 4 に打ける「流通分」 に該当する数值であり， 2007 年度末段階では使用済みとな るが，2004 年度末段階における「退蔵」と区別するために そのままの用語を用いている。 また，2009 年度以降の分析 においては，「流通分」はユーザーの意思による処理方法の 比率によって各処理方法に振り分けた. $\mathrm{Ba}, \mathrm{Cr}, \mathrm{Ni}$ につて はその具体的な量を Table 4 に示した.

この結果から輸出, 既拡散を含めて, 最終的に 4 物質の 平均では携帯電話用途としての純国内投入量の約 $28 \%$ が行 方不明の状態になると推定される. また, 販売店返却割合は 約 $56 \%$ となるが，これは退蔵者の $64 \%$ が退蔵携帯電話を将 来，販売店に返却すると答えていることによる.

\section{7. 結 論}

本論文では普及が著しく, 法的義務に基づく回収システム が未整備な状況にある携帯電話を対象として, 2004 年度末 までの国内投入台数をタイプ別に明らかににするとともに， タイプ別の平均使用期間からそれらが使用済みとなる年度と 台数を予測した. 同時に ICP 分析および EPMA 分析により タイプ別の含有微量有害物質を推定した結果と，ユーザーに 行ったアンケート調査から得られた使用済久携帯電話の処理 実態を用いて, 使用済久携帯電話に含まれる微量有害物質の SFA を行った。その結果からわかったことは以下のとおり である。

(1) 携帯電話に含有されている微量有害物質のうち PRTR の第 1 種指定物質に該当する $\mathrm{Ba}, \mathrm{Cr}, \mathrm{Pb}, \mathrm{Ni}$ の 4 種に ついてタイプ別の含有量を分析した. その結果を用いて，携 帯電話発売当初から 2004 年度末むでにすべての携帯電話生

Table 4 Estimation of substance-flow at each time.

\begin{tabular}{|c|c|c|c|c|c|c|c|c|}
\hline & \multirow{2}{*}{$\begin{array}{c}\text { item } \\
\begin{array}{c}\text { Net domestic input until the end of } \\
2004 \text { (including import) }\end{array}\end{array}$} & \multirow{2}{*}{ time } & \multicolumn{6}{|c|}{ item } \\
\hline & & & Storage & Final disposal & $\begin{array}{l}\text { Return to shop } \\
\text { (Cascade recycling) }\end{array}$ & Diffused & Export & Distribution \\
\hline \multirow{4}{*}{$\mathrm{Pb}$} & \multirow{4}{*}{102.22} & $2008^{\prime} 3$ & 35.77 & 2.79 & 24.12 & 14.19 & 9.14 & 16.20 \\
\hline & & $2010^{\prime} 3$ & 31.97 & 6.80 & 36.36 & 17.94 & 9.14 & - \\
\hline & & $2028^{\prime} 3$ & 15.48 & 11.76 & 46.85 & 18.98 & 9.14 & - \\
\hline & & $2078^{\prime} 3$ & - & 16.42 & 56.70 & 19.95 & 9.14 & - \\
\hline \multirow{4}{*}{$\mathrm{Ba}$} & \multirow{4}{*}{228.29} & $2008^{\prime} 3$ & 80.89 & 5.95 & 53.61 & 31.04 & 21.42 & 35.38 \\
\hline & & $2010^{\prime} 3$ & 72.04 & 14.87 & 80.84 & 39.11 & 21.42 & - \\
\hline & & $2028^{\prime} 3$ & 34.88 & 26.06 & 104.48 & 41.44 & 21.42 & - \\
\hline & & $2078^{\prime} 3$ & - & 36.56 & 126.67 & 43.63 & 21.42 & - \\
\hline \multirow{4}{*}{$\mathrm{Cr}$} & \multirow{4}{*}{53.32} & $2008^{\prime} 3$ & 20.52 & 1.06 & 11.60 & 6.82 & 5.21 & 8.10 \\
\hline & & $2010^{\prime} 3$ & 18.21 & 3.23 & 18.05 & 8.62 & 5.21 & - \\
\hline & & $2028^{\prime} 3$ & 8.82 & 6.05 & 24.03 & 9.21 & 5.21 & - \\
\hline & & $2078^{\prime} 3$ & - & 8.71 & 29.64 & 9.76 & 5.21 & - \\
\hline \multirow{4}{*}{$\mathrm{Ni}$} & \multirow{4}{*}{239.15} & $2008^{\prime} 3$ & 85.81 & 6.08 & 55.32 & 32.54 & 21.90 & 37.50 \\
\hline & & $2010^{\prime} 3$ & 76.55 & 15.54 & 84.03 & 41.13 & 21.90 & - \\
\hline & & $2028^{\prime} 3$ & 37.06 & 27.43 & 109.15 & 43.61 & 21.90 & - \\
\hline & & $2078^{\prime} 3$ & - & 38.59 & 132.73 & 45.93 & 21.90 & - \\
\hline
\end{tabular}


産のために国内に投入された純国内投入量を推定すると, Pb: 102 t, Ba: 228 t, Cr: 53 t, Ni: 239 t となる.

(2) ユーザーヘのアンケート調查結果による使用済久携帯 電話の処理方法は, 台数ベースで, 販売店返却 : $31 \%$, 退 蔵 : 47\%, 拡散 : 18\%, 不燃物等として処理 : $4 \%$ と, 退蔵 割合が 5 割近くを占める. タイプ別の平均使用期間は, type $1: 22$ ケ月, type $2: 20$ ケ月, type $3: 18$ ケ月である.ア ンケート調査の回答者年齢の偏りを補正した結果では, type $1: 25$ ケ月, type $2: 23$ ケ月, type $3: 20$ ケ月である.

(3) 携帯電話に含まれる対象物質の使用済久後の現状を推 定した結果では，各物質とも純国内投入量に対する割合は, 販売店返却：約 23\%, 既に拡散：約 14\%, 退蔵：約 36\% と なる. 退蔵品の適切な回収対策が今後も確立されない場合 は，退蔵品に含まれる物質が拡散する可能性が高いこと，輸 出された製品が日本国内に回収される可能性は薄いことか ら, 既拡散に加えて退蔵, 輸出も拡散すると考えると, 使用 済久携帯電話生産のための純国内投入量に対する拡散するリ スクのある割合は 4 物質の平均で約 $59 \%$ となる.

(4) タイプ別の平均使用期間から，2004 年度末までに国 内に投入されたすべての携帯電話は 2007 年度末までに使用 済みになると推定される。

(5) 退蔵品が今後, いつ, どのような方法で処理されるに ついて推定した結果では, 現状の回収体制のままである場合, 2004 年度末までに生産された退蔵携帯電話がすべて排出さ れ，何らかの処理が行われるのは 2077 年度末頃である。 た, 退蔵品がユーザーの回収意思に従って回収されても, 最 終的に販売店返却割合は 4 物質の平均で生産時投入量の約 $56 \%$ であり，約 28\%は拡散状態になると推定される.

以上のことから携帯電話に含まれる微量有害物質を使用済 み後も管理し得るシステムを構築し, 適切な循環をたは処理 を行わなけれげ長期間を経て拡散状態となり，将来にわたっ て環境中に有害性をもたらす可能性がある。そのため，微量 有害物質の拡散防止の観点からも, 退蔵品も含めた使用済久 携帯電話を回収するシステムを整備する必要がある.

本研究は, 独立行政法人科学技術振興機構 (JST) 戦略的創
造研究推進事業「サステナビリティ指標としての物質・材料 フロー」(平成 15 年度採択課題) および，科学研究費補助金 若手 B (19760588) に打ける研究内容の一部です. 名古屋大 学工学研究科の黒田光太郎教授には研究全般へのご指導とア ンケート調査実施への多大なご協力をいただきました。ここ に厚く扮礼申し上げます。また，研究を推進するにあたり， アンケート調査にご協力いただいた皆様，ご支援いただいた 皆様に厚く感謝申し上げます。

\section{文献}

1) E. Mattews, C. Amann, S. Bringezu, M. Fischer-Kowalski, W. Huttler, R. Klejin, Y. Moriguchi, H. Schutz, E. vander Voet and H. Weisz: Weight of Nations-Material Outflows from Industrial Economies, (World Resource Inst., 2000).

2) Ministry of the Environment: Law Concerning Reporting, etc. of Releases to the Environment of Specific Chemical Substances and Promoting Improvements in Their Management, 〈http://www. env.go.jp/en/laws/chemi/prtr/index.html $>,(2007 / 01 / 23)$.

3) CIAJ: Japan's Telecommunications Equipment Statistics Production/Imports/Exports 〈http://www.ciaj.or.jp/content/info/dat. html $\rangle,(2007 / 01 / 23)$.

4) Nikko Smith Barney Limited: Mobile Telecommunications Field Theory, p. 11.

5) K. Sumio: Role of the Administration to the Promotion for Cellular Phone Recycling, Institute for Posts and Telecommunications Policy (2002.10).

6) Mobile Recycle Network: Current Status of Recycling for Used Cellular Phone and PHS F Y2004.http://www.mobile-recycle.net/ news/index.html $>$, (2007/01/23).

7) Nikkei Business Publications: Nikkei Ecology (in Japanese), 9 (2000) 40-42.

8) K. Nakajima, K. Yamamoto, K. Nakano, K. Kuroda, K. Halada and T. Nagasaka: Journal of Life Cycle Assessment, Japan, 2(2006) 341-346.

9) TCA: Results of Investigation by Questionnaire concerning Recycling of Used Cellular Phone and PHS, 〈http://www.tca.or.jp/ japan/news/050621.ppt〉, (2007/01/23).

10) K. Nakano, Y. Wada and H. Oshima: Waste management research 16(2005) 1-12.

11) Statistics Bureau: Statistics data, 〈http://www.stat.go.jp/data/ jinsui/2004np/index.htm \# 05k16-b, (2007/01/23).

12) Ministry of International Affairs \& Communications: Information \& Comunication Statistics Database, 〈http://www.johotsusintokei.soumu.go.jp/statistics/statistics05b1.html〉, (2007/ $01 / 23)$.

13) Statistics Bureau: Statistics of Japan 2005, 2-21 The Average of Human Life for the Japanese. 